\title{
Gestational Trophoblastic Neoplasm pM1b TNM Finding v8
}

National Cancer Institute

\section{Source}

National Cancer Institute. Gestational Trophoblastic Neoplasm pM1b TNM Finding v8. NCI Thesaurus. Code C140026.

Gestational trophoblastic neoplasm with all other distant metastases. (from AJCC 8th Ed.) 